\title{
Mariusz Misztal
}

Pedagogical University of Cracow

\section{GIOVANNI DELLA CASA'S GALATEO: A SERIOUS TREATISE ON MANNERS OR "ONLY A JOKE”?}

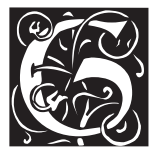
abriel Harvey (Stern 1979), protégé of the influential Robert Dudley, Earl of Leicester (Misztal 2002), and friend of Edmund Spenser, sometime between 1575 and 1580, when he was a student at Cambridge, wrote to $\mathrm{Mr}$ Wood, a gentleman at the court of Queen Elizabeth, a letter which describes his contemporaries' dissatisfaction with the traditional university curriculum". He writes that "schollars in ower age ar rather nowe Aristippi then Diogenes", active rather than contemplative philosophers, "covetinge above alle thinges under heaven to appeare sumwhat more then schollars if themselves wiste howe; and of all thinges in the worlde most detestinge that spitefull malicious proverbe, of greatist Clarkes, and not wisest men". ${ }^{2}$ They want practical knowledge which would help them to understand better the ways of the world and to make career outside the university, preferably, at court. Therefore, traditional authorities like John Duns Scotus, Thomas Aquinas or even Aristotle, with "the whole rablement of schoolemen were abandonid ower schooles and expellid the Universitye" and the students now turn to the study of modern French and Italian writers:

${ }^{1}$ British Library, MS Sloane 93, f. 42b and 43, f. 101b, published in Scott 1884, 78-9; an abbreviated text of the letter (f. 101b) is also given on page 182 .

${ }^{2}$ Cf. Ascham 1870, 36-7: "Learning is robbed of hir best wittes, first by the greate beating, and after by the ill chosing of scholers, to go to the Vniuerssities. Whereof cummeth partelie, that lewde and spitefull prouerbe, sounding to the greate hurte of learning, and shame of learned men, that, the greatest Clerkes be not the wisest men". 
And nowe of late forsoothe to helpe countenaunce owte the matter they have gotten Philbertes Philosopher of the Courte, the Italian Archebysshoperies brave Galatro [sic], Castiglioes fine Cortegiano, Bengalassoes Civil Instructions to his Nephewe Seignor Princisca Ganzar, Guatzoes newe Discourses of curteous behaviour, and I knowe not how many owtlandishe braveryes besides of the same stampe. And I warrant you sum good fellowes amongst us begin nowe to be prettely well acquayntid with a certayne parlous booke callid, as I remember me, II Principe di Niccolo Macchiavell (Scott 1884, 78-9).

And in 1580, in his "earthquake" letter to Spenser, he again comments on the reading then popular at Cambridge: "Machiavell a great man: Castilio of no small reputation, Galateo and Guazzo never so happy." (Harvey 1884, 1:168).

The above mentioned books seem to offer a representative picture of the eclectic courtesy literature available to Elizabethan readers in English translations. Of all the books in Harvey's list "Castiglioes fine Cortegiano", that is Baldassar Castiglione's Il Cortegiano, was probably most popular among the courtiers (Burke 1995) and it received recommendation even from Roger Ascham, a humanist critical of Italian influences in England, who commented that

To ioyne learnyng with cumlie exercises, Conto Baldesær Castiglione in his booke, Cortegiano, doth trimlie teache: which booke, aduisedlie read, and diligentlie folowed, but one yeare at home in England, would do a yong ientleman more good, I wisse, then three yeares trauell abrode spent in Italie' (Ascham 1870, 61).

Il Cortegiano, being an extended manual of making and self-making, argues that much of the courtier's success with his peers and sovereign depends on his ingratiating manners. In effect, Il Cortegiano presents an art of pleasing the prince, since nearly every courtesy the courtier is asked to cultivate can be used successfully to win or preserve the sovereign's good will. ${ }^{3}$ The book became more available to the English courtiers in 1561 in the English translation of Thomas Hoby 1900) and the notes in the copy of Il Cortegiano belonging to Gabriel Harvey (Rees-Ruutz 1910) show that it was studied closely. Regardless of The Courtier's popularity, Harvey's list is headed by Philibert de Vienne's Le Philosophe de court (1547), translated into English by George North as The Philosopher of the Court (1575).

3 The best studies of Il Cortegiano are Woodhouse 1978, Hanning and Rosand 1983, Falvo 1992. On various attitudes towards Il Cortegiano see also Bonadeo 1971. 
It is rather strange to find this very work in a list of popular courtesy books seriously studied by aspiring Englishmen next to The Courtier, because it was intended by its author as a subtle but devastating mockery of courtiership that pressed to extremes Castiglione's ideal (Mayer 1951; Smith 1966, 138-47; Javitch 1971). Philibert stresses that dissimulation and the art of pleasing are fundamental to be successful at Court. The courtier must be prepared to do whatsoever it be, according to the humours of his fellows and courtly company, although his affections are "cleane contrary". The true philosopher of the court dissembles in order to advance himself by pleasing everybody. Stratagems enable him to blind the world, for to be open and simple is "meet for beasts and idiots". The conventional virtues can be followed but only when it is advantageous, and one must never hesitate to abandon "such small trifling things" when they become a hindrance (Philibert de Vienne 1575, 108-9). Philibert's ironic exaggeration of Castiglione's precepts did not prevent the Elizabethans from treating the text as sensible and pragmatic advice about how to succeed at court. George North dedicated this work to Christopher Hatton, who would, he said, find in it "both flowers and fruit of courtly philosophy"(Philibert de Vienne 1575, Sig. A. 2v.).

The second work in Harvey's list is "the Italian Archebysshoperies brave Galateo"4. "The Italian Archbishop" is Giovanni della Casa, Florentine cleric and humanist, poet and writer on social issues, inquisitor and the papal curia diplomat. ${ }^{5}$ Born into a rich merchant family of aristocratic origins, to please his father he studied law at Bologna, but under the influence of the famous Latinist and Aristotelian, Ubaldino Bandinelli, ${ }^{6}$ he became passionately interested in

4 The other titles are "Bengalassoes Civil Instructions", that is as The Court of Civill Courtesie. (1577), and "Guatzoes newe Discourses of curteous behaviour" that is Stefano Guazzo's La civil conversatione (1574), translated into English by George Pettie and Batholomew Young as Civile Conversation $(1581,1586)$.

5 Practically all the available details on Della Casa's life were collected by Casotti 1733; Campana 1907-1909 is indispensable if only because it includes a selection of documents concerning the life of Della Casa many of which are no longer available to scholars. A good summary of Della Casa's life and career is Caretti 1955, but the only detailed life of Della Casa is Santosuosso 1978, which is practically the translation of his unpublished doctoral dissertation Life and thought of Giovanni della Casa, 1503-1556 (1972). The best bibliography of Della Casa's works until 1975 is Santosuosso (1979).

${ }^{6}$ Ubaldino Bandinelli (1494-1551), was the bishop of Montefiascone and Corneto; Della Casa described him in Il Galateo as "a worthy gentleman, of singular good witt and profound learning”. Peterson $(1575,31)$. Cf. Della Casa's Latin ode VI: “De Ubaldino Bandinellio" ["Honoring a Florentine Master's Gifts"] (Della Casa 1999, 54-9). 
classical literature and poetry. In 1526 he gave up his legal studies and together with his friend, Ludovico Beccadelli, spent seventeen "most precious" months in Mugello, studying the classics, especially Cicero (Giganti 1797, 1:3).

Return to Rome at the end of 1529 marked the beginning of the period of decadence, which in the future proved to be the main obstacle to Della Casa's becoming a cardinal. It is during years 1529-1537 that he composed in volgare, in style of his companion Francesco Berni, a series of witty but often obscene poems ${ }^{7}$ and became famous for his numerous love affairs. In a letter to his friend he admits:

Love has taken away from me these few feelings I used to have, and I haven't read anything for months, I haven't even opened a book. A woman, "dulcibus ille quidem illecebris," ${ }^{8}$ has changed me so much and I do not deserve the affection that you have towards my person". (Della Casa to Cosimo Gheri, 22 Nov 1532, Della Casa 1733, 4:15).

It was during his stay in Rome that Della Casa decided that taken his origins, wealth and education, the most pragmatic way to develop his future career would be to become a man of the church. He was never really religious and lacked a true vocation, but with the help of his powerful protector, cardinal Alessandro Farnese, nephew of Pope Paul III, soon after taking holy orders in 1537, he was appointed a clerk of the Apostolic Camera and granted the honorific title of Monsignore (Campana 1909, XVIII: 346). In 1540, still enjoying the protection of the Farnese family and thanks to good offices of his friend, Pietro Bembo, now also cardinal, he was made a papal collector in Florence, and four years later he rose to become Archbishop of Benevento and was appointed papal nuncio in Venice (Campana 1907, XVI: 267).

During his stay in Venice he found himself in the middle of religious controversies of the day (Santosuosso 1973) and was supposed to be the censor of the morality of others and, as the official representative of the Holy Office of the Inquisition in Venetian territory, the controller of religious correctness (Santosuosso 1978a; Martin 1993, 53-74). In his capacity of the inquisitor he was responsible for conducting the heresy proceedings against Pier Paolo Vergerio,

7 Della Casa (1538). They include Del Baccio ["On the Kiss"], and Sopra il forno ["On the Oven"], a metaphor for the female sexual organ. He also wrote a satire in the style of Berni on the minuteness of his sexual organ. Santosuosso (1975, 461-95); Santosuosso (1978, 33-46).

8 The phrase "she indeed with her sweet lures" was used by Vergil of a cow that distracts and weakens bulls. Georgics 3. 217. 
Bishop of Capodistria, who used the opportunity to attack Della Casa's dissolute past life in Rome and his obscene terzine burlesche. ${ }^{9}$ The years of nunciature gave him stimulus to reflect upon the hot Renaissance issue: clash between civil duty and moral law-ragion di stato and morale. ${ }^{10}$

With Pope Paul III's death in 1549, Della Casa's high hopes to be rewarded with a cardinalate for his faithful service to the papacy and his unwaiving support of the Pope's anti-Spanish policy were dashed. ${ }^{11}$ As the new Pope, Julius III, was hostile towards the Farnese family, Della Casa, pleading ill-health, refused to become the new pontiffs nuncio in France and retired from court life.

Choosing a country life, he wanted "di vivere in quiete, e in riposo con ozio e comodità di starmi tra I miei libri, e nel mio studio quanto mi fa di piacere" ["to live in tranquillity, rest and idleness amongst my books and studying as much as I please"]. ${ }^{12}$ When five years later, the new pope, Paul IV Carafa recalled Della Casa to Rome and nominated him his secretary a litteris italicis (Ancel 1906), his hopes of becoming a cardinal were revived again. Although his nomination received the support of the French king, it provoked numerous disputes, because the severe Paul IV wanted among his cardinals only the most religious persons who led austere lives. ${ }^{13}$

Della Casa understood that his past libertine life and the few obscene poems written in his youth, stood again in the way of making the dream of his life

9 See: Della Casa $(1547,230)$. Della Casa, wrote the Dissertatio to prove himself innocent of the accusations brought up against him by Vergerio, and he accused the wellconnected Vergerio not so much of a religious reformation as of provoking a social rebellion.

${ }^{10}$ It is in Della Casa's oration Orazione a Carlo V imperadore intorno alla restitution della città di Piacenza, ["Oration for Charles V Emperor, in the Event of the Restoration of the City of Piacenza"], a passionate address to Charles V begging him to give Piacenza back to the Farnese family, that the first known use of the term "reason of state" is found. Lisio (1897, 249-283); Mattei (1969).

${ }^{11}$ In November 1547 Della Casa wrote to Cardinal Farnese expressing his hope and desire "to be distinguished", "d'essere onorato". Della Casa (1733, 5:126). On Della Casa's resentment towards Paul III for not being made cardinal, see Della Casa to Gualteruzzi, 16 November 1549 (Della Casa 1733, 5:272).

12 Della Casa to Ludovico Beccadelli, 23 August 1550 (Della Casa 1733, 4:28).

13 Della Casa to Rucellai, 20 September 1555 (Della Casa 1733, 5:65). Although the former pope, Paul III, fathered four children and elevated to cardinalate Bembo, who had three, now it was brought up that Della Casa fathered a Venetian bastard. Della Casa's son was accused of assassinating a Florentine merchant and then beheaded in 1582 (Santosuosso 1978, 135-136). 
come true ${ }^{14}$, and he sent a letter to Cardinal Farnese who was responsible for making appointments at the papal curia to remove his name from the list of the candidates. ${ }^{15}$ Four months later Della Casa's health seriously deteriorated and he died on 14 November 1556.

During his retirement at the Abbey of Nervesa sul Montello near Treviso, Della Casa's literary activity intensified and he composed his most important literary works which would make his name in Italian letters, ${ }^{16}$ namely, the largest part of his Rime, which show him as a wretched and embittered person, ${ }^{17}$ and the famous treatise on manners, Il Galateo.

Il Galateo was not, however, Della Casa's first attempt at a book of manners. Probably by 1543 (Carrai 1980), he wrote a treatise on office-holding, De officiis inter potentiores et tenuiores amicos (Della Casa 1733, 6:35-54) in which he presented his reflections on mechanisms of newly formed bureaucracy providing the reader with practical instructions on how to command and serve to harmoniously develop power relations. Written in Latin, it was published in an Italian translation as Trattato de gli uffici comuni tra gli amici superiori et inferiori [1569] (Della Casa 1733, 5:335-61) and into English [1665] (Stubbe 1665).

Despite the title, this treatise has little to do with Cicero's De officiis (Santoro 1967, 215-252; Romano 1971, 169-186; Pissavino 1988, 51-90). The bureaucratical relationships, both antiquated and modern, are illustrated in the treaty as the relationships between amici superiori-superior friends and amici inferioriinferior friends, who are also called servi or persone basse. There exists a relationship between the two groups which is based on partnership, and Della Casa even compares superiore to a father of a family who is severe but just and who guides

${ }^{14}$ In 1673, Obadiah Walker, reputed author Of Education. Especially of Young Gentlemen, to underline that caution in writing is of the utmost importance relates an adectode about Della Casa: "For going to to present to the Pope a petition, by mistake he delivered a copy of licentious Verses writ by himself: whereby he lost the Pope's favour, his own reputation, and all hopes of advancement" (231) (qtd. Mason 1935, 263).

${ }_{15}$ Della Casa to Alessandro Farnese, 14 February 1556 (Della Casa 1733, 5: 67).

${ }^{16}$ A good analysis and list of Della Casa scholarship in the twentieth century is Cordie (1971). The latest bibliography is included in the three important volumes of modern criticism of Della Casa’s works, Barbarisi and Berra (1996), Quondam (2006), and Carrai (2007).

17 The Rime published for the first time in 1558, and consisting of 70 sonnets and four canzoni, were regarded by critics "the most beautiful canzoniere of the sixteenth century" (Benedetto Croce), and "the most significant poetry to emerge between Ariosto and Tasso" (Carlo Dionisotti). He also wrote then most of the Latin poems published as Ioannis Casae Carminum Liber in Latina monimenta Ioannis Casae, ed. Pier Vettori (Florence, 1564), which was edited and translated in Della Casa 1999. 
himself by the welfare of his children. The "friendship" between amici superiori and inferiori is not gratuitous - the only one thing that joins these two worlds is money; thus, Della Casa admits that it is money which is the crux of the relationships based on subordination and the bureaucratical friendship is possible only between those who are wealthy, and between those who are not wealthy. In this case nobility does not matter at all—one may be of noble birth, may be educated and virtuous but still, if one does not have at least a slender fortune, which would enable him to buy superiorita, one will not be allowed to become one of superiori. But De officiis does not so much support the idea of class society in which money counts more than ancestry, as rather highlights the problem of relationships between ricchi nobili and poveri nobili and at raising an issue of career and its cost.

De officiis shows also Della Casa's inclination to moralise. He shows that he fully understands that the superiors are cose noiose, but, simultaneously, he says that it is how the world is created and a common person cannot but agree with this order. He advises uomini bassi to be patient, modest and humble. Although the English translator of De officiis, Henry Stubbe claimed that Della Casa "preferred this [De Officiis] before his Galateus" and that in his Latin style Della Casa surpassed "all others" but Cicero, ${ }^{18}$ all in all, this pedantic attempt at a book of manners was largely a failure (see: Richter 1966, 87-100).

In the period from 1552 to 1555 , during his self-exile Della Casa composed the famous Galatheo, ò vero dé costumi. Della Casa was not willing to publish the treatise. Indeed, he published little during his lifetime, only the Terze rime and a handful of poems in anthologies (Santosuosso 1979, Nos. 1-18). The main reason was that he was never happy with his compositions, he thought and rethought his works, and he was "so fastidious about his style as to seem almost neurotic" ${ }^{19} \mathrm{He}$ was also very sensitive to public opinion, and he was convinced that his works, which he considered "frivole et non finite" ["frivolous and incomplete"] ${ }^{20}$ (Annibale Rucellai to Pier Vettori, 1 January 1564 in Santosuosso 1979, 111), could never bring him a scholar's reputation. Indeed, he seemed to consider a few introductory pages of an unfinished treatise on the quality and use of Italian, Greek and Latin, his most important work (Della Casa 1733, 4:31-34). ${ }^{21}$

${ }^{18}$ Stubbe's Introduction to his translation, after The Dictionary of National Biography (Oxford, 1963-4), s. v. "Stubbe [Stubbes, Stubbs], Henry (1632-1676)", 116-17.

19 Santosuosso 1979, 1; he prints also an important selection from the correspondence of "Annibale Rucellai to Pier Vettori on Della Casa's works and last year of Life", at 91-119.

${ }^{20}$ Annibale Rucellai to Pier Vettori, 1 January 1564 (Santosuosso 1979, 111).

${ }^{21}$ Annibale Rucellai to Pier Vettori, 11 July 1562 (Santosuosso 1979, 106). 
Three months before his death he requested his nephew Annibale Rucellai to burn all his compositions, ${ }^{22}$ and it was only thanks to the enthusiasm and diligence of Della Casa's secretary's, Erasmo Gemini de Cesis, and the demands of many relatives, friends and patrons that Annibale Rucellai, the heir of his uncle's works, was convinced to allow the publication of Della Casa's Italian works. ${ }^{23}$ The Rime, et prose volume included, apart from a sequence of Italian lyric poems and Orazione scritta a Carlo V imperadore intorno alla restitution della città di Piacenza, also the first edition of Galateo (Della Casa 1568). The front page of the treatise announced the following explanatory subtitle: Trattato / di Messer Giovanni Della Casa, I nel quale sotto la persona d'un vecchio / idiota ammaestrante un suo giovinetto / si ragiona de' modi, che si debbono, o / tenere, o schifare nella commune / conversatione, cognominato / Galatheo / overo de' costumi. ${ }^{24}$

Galateo won immediate popularity throughout Europe and by the end of the sixteenth century had been translated into French (1562), English (1576), Latin (1580), Spanish (1585), and German (1597). Nowadays, in Italian "sapere il Galateo" - to know the Galateo, is a phrase signifying that one is polite.

In 1576 Galateo was translated into English by Henry Peterson..$^{25}$ It was reprinted two years later and till 1774 it was printed six times in four different translations. ${ }^{26}$ In addition, there appeared from 1616 to 1804 twenty-one

22 "Mi disse di far abbruciare tutte le sue compositioni, perche erano imperfette, ne vi era cosa di di valor nessuno". Annibale Rucellai to Pier Vettori, 6 September, 1561 (Santosuosso $1979,103)$. This brings to mind the legend that the dying Vergil ordered his unfinished Aeneid destroyed, but Augustus had it published.

23 Annibale Rucellai to Pier Vettori, 29 January 1559 (Santosuosso 1979, 100).

24 ["Treatise of Mister Giovanni Della Casa in which, under the persona of an ignorant old man, he instructs a young man on what to do and what not to do in common conversation, thus called Galateo, or of manners"]. The editio princeps of Galateo was published without chapter divisions or a preface. In the 1578 edition (Florence: Giunti), an editor added a prefatory index of "le cose più notabili" [the most noteworthy things] in the book, but left the whole text intact. The chapter divisions were established in the eighteenth century, in the Pasinello edition of the Opere di monsignor Giovanni della Casa (Venice, 1728). Critical editions of the text were published, e. g., by Bruno Maier as Della Casa, G., 1971, and - from the only surviving manuscript — by Genaro Barbarisi as Della Casa, G., 1991. The extensive secondary material on Galateo in Italian is given by Stefano Prandi in Della Casa, G. 2000, lii-lix.

25 His translation is probably based on the anonymous 1573 French version. On Peterson's translation (1576), see (Avila 1997 and 1998).

26 Santosuosso 1979, 9-11, Nos. 61, 62, 132 (1701, translated from Nathan Chytraeus's Latin version by "several young gentlemen educated at a private grammar 
printings of English paraphrases of Galateo. ${ }^{27}$ The model of behaviour offered in Galateo still seemed marketable in the United States as late as 1811, when a London version was pirated and combined with a handbook on carving meats at table. ${ }^{28}$ Since 1900 there have appeared three new translations of Galateo into English. ${ }^{29}$

The title of the treatise is derived from the Latinized form of Galeazzo, $G a$ -

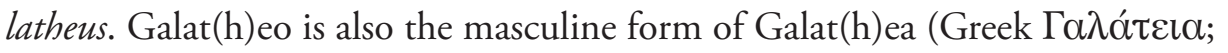
"she who is milk-white"), connected today with the myth of Pygmalion, a Cypriot sculptor, who carved out of ivory a woman so beautiful and life-like that he fell in love with it/her. In answer to his prayers, the goddess Aphrodite brought the statute to life and united the couple in marriage. ${ }^{30}$ This allusion has been said to represent the purpose of the book- "the search for human ideals and the means of animating those ideals through fulfilling the potential in all men" (Della Casa $(1990,63)$; cf. Della Casa $(2013,85-6)$, and Berger $(2000,202-$ 204)). ${ }^{31}$ But despite this seemingly obvious allusion, it is impossible that Della Casa could have made it purposefully, for no ancient text mentions the statute's name, and the name "Galatea" was first used for it only in 1762 by Jean-Jacques Rousseau in his Pygmalion (Law 1932; Reinhold 1971). Della Casa must have

school near Hackney"), 133 (1703, a free rendition of the Latin version by Barnaby Bernard Lintott), 171 (1763), 178 (1774, translated, or at times paraphrased, by Richard Graves (Della Casa 1774), 270 (1892 reprint of No 61), 291 (reprint of No 61), 324 (1969 reprint of No 61).

27 Santusousso 1979, Paraphrases of Galateo: No 12 (1616), 18-28 (1640), 29 (1663), 31 (1668), 32 (1679), 34 (1686), 35 (1689), 42 (1778), 45 (1804). On Della Casa's influence in England, see Scott (1916, 459-66) and Tilley (1918).

${ }_{28}$ Galateo, or, A Treatise on politeness and delicacy of manners: from the Italian of Monsignor Giovanni de la Casa... also The Honours of the Table, with the whole art of carving illustrated with a variety of cuts (Baltimore: printed for George Hill; B. Edes, printer, 1811). Cf. John van Sickle's Introduction to Della Casa 1999, 3.

29 They include: Della Casa (1958), which is often considered a paraphrase since it omits some phrases; Della Casa (1990), and, quite recently, Della Casa (2013), whose translation is based on the text of the treatise as preserved in the only surviving manuscript of Galateo, edited in Della Casa (1991).

30 The story of Pygmalion appeared earliest in a Hellenistic work of Philostephanus of Cyrene ( $3^{\text {rd }}$ c. B. C. ), history of Cyprus, De Cypro, and it is retold in Ovid's Metamorphoses (10. 242-97).

31 Interestingly enough, the name Galatea is given to Della Casa's work by Laurence Sterne in his The Life and Opinions of Tristram Shandy, Gentleman (1759), chap. XVI, but in reality Sterne probably never read, or even saw, the book for he seems to think it was a romance. Cf. Robert Graves' “Introduction” to Della Casa (1774, vii). 
known, however, the myth of the nereid Galatea who was in love with Acis, the spirit of the Acis River in Sicilly, eventually killed by his jealous rival Cyclop Polyphemus (Ovid, Metamorphoses 13. 750-897).

The Galateo of Della Casa's treatise is Galeazzo Florimonte, bishop of Aquino and then of Sessa, a witty censor of human habits and vices, whom Della Casa befriended during his residence in Rome. ${ }^{32}$ According to Erasmo Gemini de Cessis, Della Casa's secretary, during one of their numerous discussions, Florimonte suggested to Della Casa writing a book on human manners:

d'uno in altro ragionamento passando, vennero a dire del vivere civile e politico, e della leggiadria e convenenza de' costumi, e delle sconcie e laide maniere, che gli huomini usano bene spesso infra di loro; alla fine soggiuse il Vescovo, che allui molto a grado sarebbe di vedere intorno a' modi che la gente nell'usanza commune dee tenere o schifare, un Trattato nella nostra vulgar favella, acciocché più largamente comunicar si potesse". [passing from one subject to another, they started to talk about civil and political life, about prettiness and advantages coming from customs, indecent and filthy behaviours that men often perform; finally the Bishop added that it would be a pleasure for him if he could see around manners that men have to apply or disgust, a Treatise written in our vernacular speech, that could be widely spread]. (Erasmo Gemini's introduction "Ai Lettori" [To the Reader] in Bevilacqua's edition of $I l$ Galateo (Della Casa 1991, 120).

Florimonte, continues Gemini, praised Della Casa’s literary capacities and expressed his readiness to help the poet to write the treatise, using as an example the praiseworthy behaviour and conduct he met with during his stay at Giovanni Matteo Gilberti, ${ }^{33}$ the bishop of Verona's house.

In his Life of Cardinal Contarini, written before October 1552, Della Casa describes Florimonte as

32 Galeazzo Florimonte (1478-1567) was the translator of Plato and the author of the learned Ragionamenti Sopra l'Etica di Aristotele (1554); he himself started, but never completed, his own book of manners, Libro delle Inezie o un Trattato delle Buone Creanze. D’Onofrio (1938) and, especially, Biadego (1900-1).

33 Giovanni Matteo Gilberti (1495-1543), theologian, papal diplomat, from 1524 bishop of Verona, was one of the organisers of the Council of Trent. In Galateo (20-21) he is described as: "a bishop, a wise man, a learned \& of a singular good wit by nature... Amongst many good parts yt were in him he was very courtious \& Iiberall, to all gentlemen $\&$ noble men that came unto him, doing them all ye honor he could in his house, not with over much pompe and cost, but with convenient entertainement and measure, such as besemed well a man of the Clergie". 
vir cum omnibus honestis artibus perpolitus, tum praecipue castus, atque integer, tum religion, ac pietate in primis incensus; in notandis autem, reprehendendisque amicorum vitiis unus omnium maxime acer, ac liber, castigator nonnumquam etiam subamarior [a man adorned not only with every genteel manner, but above all with a chaste and irreproachable manner of living, and he is also very fervent in his religious practices and piety. He is more shrewd and open than anyone else in noticing and reproving his friends' faults, and sometimes he is even a critic who is not quite restrained]. ${ }^{34}$

In Galateo (22-23), Galeazzo Florimonte is described as "a man well strooken in yeares, very lerned, and mervailous pleasaunt, welspoken, comely, and had muche frequented in his time, ye Courtes of greate Princes," and Della Casa adds that it was at Florimonte's "request and councell, I first tooke in hand to set forth this present treatise" (21-22).

The treatise has a form of a monologue of an uneducated old man, who gives instructions to his young relative to show him the benefits of good manners and proper behaviour. The subtitle of the book says that the instructions are given "under the persona of an ignorant old man", a narrator who is distanced from Della Casa. According to some critics, this impersonization "dramatizes antipathy towards a discourse aimed at alienating what was once rightfully the special property of nobles like himself and making it "the common property of all men'” (Berger 2000, 212).

Galateo was probably dedicated to Della Casa's nephew, Annibale, ${ }^{35}$ who was to become his uncle's heir. And it seems that the book is meant for men rather than women. Some women are mentioned in Galateo, and they are usually given as examples of defective behaviour (cf Berger 2000, 223). Following the tradition of misogynist writing, already by 1537 Della Casa composed in Latin a controversial treatise on marriage, Questio lepidissima: An uxor sit decenda ["A Delightful Question: Whether One should Wed"], which presents women as inferior creatures in every aspect of life (Della Casa 1733, 6:239-72). Della Casa presents women as mischevious and wicked creatures and concludes that not only is marriage unnecessary, but that it is even useless while making love to the same person is boring.

34 Della Casa 1733, 5:91. Quoted in Della Casa 1990, 65 (but it is mistakenly written there that the quote is from Della Casa's letter to Contarini).

35 Della Casa's sister, Dianora married Luigi Rucellai, of an ancient and influential Florentine family. They had two sons, Annibale (?-1601) and his younger brother Orazio, who, rather than Annibale, is sometimes named as the addressee of Galateo. Cf. Santosuosso (1975a, note 44). 
The narrator in Galateo tries to convince his young disciple that it is very important to start learning good manners as early as possible:

(...) if in mine infancie, when minds be tender and pliable, like a young twigge, they that had ye charge $\&$ governement of me, had had the skill to smoothe my manners, (perhaps of Nature somewhat hard and rude) and would have polished and wrought them fine: peradventure I should have beene such A one, as I travaile to make thee Nowe, whome I love no lesse then if thou were my sonne. (95)

It may seem strange that Galateo pays so much attention to any minute gestures and daily acts, but as the old man explains, since he is still too young to grasp the "more principall and higher precepts", he would be taught what many may perhaps consider "but trifles" but in really are "very nere to virtue":

I meane what manner of Countenance and grace, behoveth a man to use, that hee may be able in Communication and familiar acquaintance with men, to shewe him selfe plesant, courteous, and gentle: which neverthelesse is either a vertue, or the thing that comes very nere to vertue (13-14). ${ }^{36}$

And although the law decrees no "paine for unmannerly \& grose behaviours", "nature herselfe" punishes us for it by putting us "besydes ye companie \& favour of men", because people hate "ye unmannerly \& untaught" as much, if not more, than "ye wicked". It is underlined that our manners have "some pleasure in them when we respect other men, and not our owne pleasure" and therefore we must adapt our manners according to the pleasure of those who are around us. But it must always be done by "discrezione" [discretion] (Santoro 1978) and measure, ${ }^{37}$ for if one "applieth himself to much, to feede other mens humors, in his familiar conversation, and behaviour with men, is rather to be thought a Jester, a Jugler or Flatterer, then a gentleman wel taught and nourtured" (16). And on the contrary, someone who has "no care or mind to please, or displease" is a rude, "untaught, and uncourteous fellowe". Conformity is also

${ }^{36}$ This last remark could possibly be deemed Della Casa's only contribution to the philosophy of manners. See Adams (1947, 458).

37 "Misura", "mezzanamente" The ideal of "golden mean" goes back to the tale of Daedalus who warns his son to "fly the middle course" between the sea spray and the sun's heat; another early elaboration is found on the front of the temple in Delphi "nothing in excess". See Aristotle, Nichomachean Ethics, II. 8, or Horace, Odes II, x, 5 (aurea mediocritas). On the importance of the norm of the via media, or mediocrità, in Castiglione's Courtier, see Hoby (1900, 134); Woodhouse (1978, 71-2). 
important, for we should adapt to the wishes of the majority, and thus we shall be able to find out which "the meanes and ways to choose and eschewe" for living in a society (16).

Thus, according to Galateo, the desire to please is the aim of all good manners. While Galateo teaches what forms of conduct are pleasing, it concentrates on displeasing behaviour that must be shunned, reflecting the increasing tendency of later Renaissance moralists to regulate behaviour (especially concerning bodily functions) in public (Elias 1978, chap. 2), and a large part of the book is concerned with the correction of all kinds of conversational faults. $G a-$ lateo provides no new theory of courtesy, and its rules of etiquette do not seem very different from those in prior handbooks like Caxton's Book of Curtesye $e^{38}$ or Erasmus' widely read De civilitate morum puerilium ["On Good Manners of Boys"]. ${ }^{39}$ Unlike his predecessors, however, he does not limit attention to one aspect of polite conduct, but seeks to formulate a code of good manners, based on decorum and prevailing custom, that could apply to every civil person, regardless of his class.

There are various ways of looking at the Galateo. It was compared to Castiglione's Il Cortegiano and called "the very Sanchyo Panza to Castiglione's Don Quixote" 40 , and it was observed that The Courtier is to the Galateo "what a theory of jurisprudence is to a record of the decisions of a police-court magistrate", meaning that Galateo is less concerned with the principles of the law than with its maintenance in lesser matters and that is why its evidence is mainly negative (cf. Adams 1947, 457). If Il Cortegiano is sometimes seen as an example of literature aiming at the repression of the social mobility—-the collective depiction of the ideal courtier was designed programmatically to disgrace many "untowardly Asseheades, that through malapartnesse thinke to purchase them the name of a good Courtier" (Hoby 1900, 41)—some critics claim that Galateo

38 There is an amusing contrast between elaborate rules of etiquette and the reproofs given to young men, some of whom apparently needed very elementary instruction like "Be ware also no breth from you rebounde/Uppe ne downe, be ware that shamefull sounde". Caxton 1477-8, 11. 202-3.

39 It first appeared in 1530, running to twelve editions in 1530 alone. Robert Whytyngton's English translation was published in 1532 and reprinted in 1534, 1540, 1554. Until 1893 more than 130 editions are recorded. For its importance in the history of courtesy literature, see Elias (1978, 53-9). For a comparison between Galateo and De civilate morum puerilium see Mason (1935, 39-40).

40 Raleigh's “Introduction” to Hoby 1900 (lxiii). 
aims his precepts at a larger segment of society, which could be the reflection of the increase in number and social importance of "gentle folk" who were not highborn aristocrats or courtiers. ${ }^{41}$

Thus Galateo could be seen as the "last Italian democratic treatise" (Toffanin 1965, 253) written for "the middle class citizens rather than for the courtly aristocrat" (Dickens 1972, 126) or for "gentiluomini of Italian cities" (Bryson 1998 , 128). Other critics, however, see Galateo as "a perfidious class weapon used to differentiate the masses from the elite" (Romano 1971, 169-70), because the rules and the way of life described in the treatise are typical of the aristocracy in the cinquecento, not of the middle class, and by establishing rules on how to dress, how to eat, how and what to say in conversation, Galateo helps to reinforce the barriers between the elite and the masses (Santosuosso 1975a, 8-9). Still, other critics see Galateo as "a kind of confession, of general examination of himself and so as a kind of spiritual will" (Chiari 1946, 120) or "the will of the public man and man of society" (Caretti 1955, 74). But there seems to be at least one more way of looking at Galateo and seeing it not as a serious treatise but, partially at least, as a joke.

Already in 1774, Richard Graves wrote in the introduction to his (unsigned) adaptation of Galateo:

It may be said, perhaps, that many of the precepts here delivered (especially the former part of the Treatise) are ridiculous; and cautions against indelicacies, which no one of any education can, in this age, be guilty of.

And then he continues:

If by ridiculous is meant laughable, this indeed I must acknowledge; as The Author seems to have placed these foibles in as strong and humorous a light as possible, in hopes of laughing people out of them. And I defy any man to read many of his reflections with a serious countenance: not to mention the merit those little satirical strokes have (like the characters of Theophrastus) in giving a curious picture of the affectations and fopperies of the age, in which they were written (Della Casa 1774, ix-xii).

Indeed, Galateo's explicit advice on how not to behave in public- - for example, after you have blown you nose not to inspect the contents of your hand-

${ }^{41}$ Cf. Stone $(1965,21-53)$. Another indication of the change could be the gradual displacement of the word courtesy (from court) by the Latinate word civility (civil, civic) to denote polite conduct. On this point, see Nicholls (1985, chap. 1) and Bryson (1999). 
kerchief, or as the narrator puts it, "not to glare upon thy snot" as if you had "pearles and Rubies fallen from thy braynes" (19)—can often make the reader laugh.

We do not know how Della Casa felt about Galateo, because he nevaer mentioned it in his correspondence with friends. But his nephew, Annibale Ruccelai, writes in his letter (29 January 1559) to Pier Vettori, a Florentine philologist who prepared for publication Della Casa's Latin poems: "so che non era stimato dal compositore per cosa di momento alcuno" ("I know that the author considered it [Galateo] to be of little worth”) (qtd. Santosuosso 1979, 100). This letter allows us also to view Galateo as not necessarily a serious treatise, because Annibale Rucellai also writes that "Il Galateo fu fatto solo per scherzo et per vedere come la nostra lingua tollerava quello stile cosi humile et dimesso" ["Galateo was made only as a joke and to see how our language would tolerate a humble and modest style"] (qtd. Santosuosso 1979, 100).

The text of the treatise contains numerous allusions to the debate on the Italian language, "questione dell lingua", a longstanding debate over which form of the lingua volgare should become the standard Italian language. Della Casa's friend, Pietro Bembo in his Prose della volgar lingua suggested that Tuscan Italian, as exemplified by the work of Petratch (for poetry) and Boccaccio (for prose), rather than Dante, should be the model for the literary Italian. The narrator in Galateo, trying to emulate Boccacio's style and often quoting from Decameron (Bonora 1956; Marconi 2002), speaks in a contemporary idiom, using "humble and modest" style, making the treatise one of the finest and most elegant examples of Renaissance Italian prose writing (Morgana 1997).

Galateo discusses the language problem when giving tips on graceful speech, and the narrator, being at times "humorously ingenious" (Parker 1010, 77), is at pains to criticise the bluntness of Dante's certain words and phrases in the Divine Comedy. ${ }^{42}$ Stressing the need to use words which are easily understood, not obsolete, well-sounding and reminiscent of no evil associations, and to avoid double meanings, indecent or bitter words, the narrator warns against choosing Dante as a rhetorical model_- "I would not councell you to make him your Maister in this point, to learne A Grace: forasmuche as he him selfe had none" (76)—because he was "somewhat proude for his know ledge, scornefull and disdainfull, and muche (as Philosophers be) without any grace or courtesie: having no skill to behave him

42 For Della Casa being critised for writing thus about Dante's language, see Annibale Rucellai to Pier Vettori, 29 January 1559, Bologna (qtd. Santosousso 1979, 100). 
selfe in company." (76). ${ }^{43}$ Then the narrator gives some examples of Dante's "unhonest, foule \& filthie" (81) lines from the Divine Comedy:

She blewe large blastes of winde

Both in my face and under. ${ }^{44}$

or

I pray thee tell mee where about the

hole doth stand.

And one of the Spirits said.

Then come behinde and where the hole is, it may be scand. ${ }^{45}$

The narrator takes out the quoted phrase from its original context where they are obviously innocuous only to underline possible salacious meanings (winde=flatulence; hole=anus), thus practicing what he condemns, namely, that every gentleman must avoid saying indecent words (For more examples, see: Peterson 1576, 80-3; cf Parker 2010, 77-8).

Regardless of whether Galateo was really meant solo per scherzo (only as a joke) or not, it is, indeed, full of humourous elements. To start with, the monologue is delivered by an old uneducated man, called in the explanatory subtitle of Galateo's first edition a vecchio idiota. ${ }^{46} \mathrm{He}$ admits that he did not learn much from books in his youth - "althoughe I profited litle in my Grammar in my youthe"(66-7) — but he knows a lot thanks to his gifts of observation and careful listening. He is also of the opinion that as far as manners are concerned, practice is more important than theory:

43 This description of Dante was taken from Giovanni Villani's La nuova cronica [fourteenth century] (1991, ix, 136).

44 "se non ch'ai viso e di sotto mi venta; [("except for the wind blowing in my face and from below”], which describes the wind striking Dante's face during his ride on Geryon's back. Dante, Inferno XVII, 117, the English translation after Dante (1980).

45 "però ne dite ond'è presso pertugio/.../ E un di quelli spirti disse: Vieni dirietro a noi, che troverai la buca" " "tell us again where the opening is at hand". (...) and one of those spirits said: "Come behind us and thou shalt find the gap". ], which is part of Dante's request for directions on the mountain of Purgatory. Purgatorio XVIII, 111, 113-4.

46 Idiota, Latin "ordinary person, layman; outsider," in Late Latin "uneducated or ignorant person," from Greek idiotes "layman, person lacking professional skill” (opposed to writer, soldier, skilled workman). 
It is not inough to have knowledge and Art, in matters concerning maners \& fashions of men: But it is needefull withall, to worke them to a perfect effect, to practise and use them muche: which cannot be had uppon the soudaine, nor learned by $\&$ by: but it is number of yeares that must winne it. (94)

His presentation of the teachings is discontinuous and often disordered, repetitions are common and recurrent, and he often deviates from the subject. He tries to imitate high and "learned" style, starting the treatise with the pompous preposition—Conciossiacosache ${ }^{47}$ — which has become proverbial in Italian literature as an example of academic affectation. ${ }^{48}$ The vecchio idiota often alludes to and quotes the classics. He draws from Aristotle, Socrates, Cicero, Terence, and Plutarch as well as from humanistic writers, namely Erasmus and his De Civilitate Morum Puerilium. He often does it, however, in a way that indicates his lack of education, confusing classical details or names, which would be well known to any educated person. For example, he says that "the Graecians doe muche commend a goodman of that time, Socrates, by name, for that hee sat out one whole night long, drinking a vie with another good man, Aristophanes,"(111) calls Socrates "a Catholike"(112), confuses Seigneur de Châtillon-sur-Marne (Boccaccio's "Siri di Ciastiglione") with Count Baldassare Castiglione the author of Il Cortegiano. ${ }^{49} \mathrm{He}$ shows himself as a society man, saying, e. g. , "I have heard it saide (for you knowe I have byn familiarly acquainted with learned men in my time) that "Pindarus that worthy man" (116), and alluding to Aristotle's catharsis, he says that he heard that "these dolefull tales, which wee call Tragedies" were written to make people weep to heal them of their "infirmitie", but he claims that if there should be someone who "hath suche weeping disease", rather than go to the theatre to see a tragedy, "it will bee an easie matter to cure it, with stronge Mustard or a smoaky house" (39). The mistakes or gaffes made by the vecchio idiota, or his original ideas, are meant to make the text more humorous.

47 "For as muche as" (Peterson 1576, 13); "In as much as" (Della Casa 1958, 3; Della Casa 1990, 3); "Since it is the case" (Della Casa 2013, 3).

48 The phrase derives from a standard medieval Latin rhetorical phrase, cum id sit causa quae. The Florentine chronicle of Giovanni Villani (c. 1275-1340), La Nuova Cronica, opens the same way. Vittorio Alfieri (1749-1803), the "father of Italian tragedy", wrote that he tossed Galateo out the window in disgust the moment he saw the opening phrase- "me prese un tal impeto di collera, che seagliato per la finestra il libro" (Alfieri 1903, 1: Epoca quarta, 140).

49 Decameron VI. 10. Peterson 1576, 43, makes him "King of Castiglio". 
Galateo teaches that it is fine for gentlemen and ladies to make jokes, for we all like better people who can "stint after a friendly and gentle sort" than those who "cannot skill or have no wit to doe it." We like "jestes" because they give us "some sporte, and make us merry, and so consequently refreash our spirits: we love them that be pleasaunt, merry conceited, and full of solace". But if it is "convenient and meete in company, to use pretty mockes, and otherwhile some Jestes and taunts", we have to be careful not to confuse joking with mockery (67-8). There is no difference between joking and mocking except in purpose and intention: joking is done for amusement, and mocking is done to hurt. Therefore it is good manners to abstain from mocking anyone. Similarly, one must not "jeaste in matters of weite, and much lesse in matters of shame", because where laughter has no place, there "to use any Jestes or daliaunce, it hath a very colde Grace" (69).

It should also be remembred that "jestes must bite the hearer like a sheepe, but not like a dogge", because in the latter case it would not be a jest, but an insult. Galateo warns that not everybody is good at telling jokes and where the joke is "pretty" there "a man straite is merry" showing his liking by laughter and a kind of astonishment, but if there is no laughter the fault is the speaker's, so "hould thy selfe still then, and jest no more" (70-71).

Taking into consideration the opinion of Annibale Rucellai and the text of the treatise itself, it seems that it is "an elaborate, ironic exercise in comic-serious style" ("Introduction", Della Casa 2013, xxiv), and it is difficult not to agree with the opinion of the leading Italian scholar that perhaps Galateo has been for too long viewed as "too serious with respect to how the work was for its author" (Berra 1996, 332). 